\title{
EDUKASI PENGGUNAAN TRANSPORTASI PUBLIK DKI JAKARTA DI MASA PANDEMI COVID-19
}

\author{
Bagas Darmawan $^{1 *}$, Marsella Dwiyanti ${ }^{2}$, Alif Fatkhan ${ }^{3}$, Dini Safitri ${ }^{4}$ \\ ${ }^{1}$ Program Studi Ilmu Komunikasi, Fakultas Ilmu Sosial, Universitas Negeri Jakarta \\ Jl. R.Mangun Muka Raya, RT.11/RW.14, Rawamangun, Kec. Pulo Gadung, \\ Kota Jakarta Timur, Daerah Khusus Ibukota Jakarta 13220 \\ ${ }^{2}$ Program Studi Ilmu Komunikasi, Fakultas Ilmu Sosial, Universitas Negeri Jakarta \\ Jl. R.Mangun Muka Raya, RT.11/RW.14, Rawamangun, Kec. Pulo Gadung, \\ Kota Jakarta Timur, Daerah Khusus Ibukota Jakarta 13220 \\ ${ }^{3}$ Program Studi Ilmu Komunikasi, Fakultas Ilmu Sosial, Universitas Negeri Jakarta \\ Jl. R.Mangun Muka Raya, RT.11/RW.14, Rawamangun, Kec. Pulo Gadung, \\ Kota Jakarta Timur, Daerah Khusus Ibukota Jakarta 13220 \\ ${ }^{4}$ Program Studi Ilmu Komunikasi, Fakultas Ilmu Sosial, Universitas Negeri Jakarta \\ Jl. R.Mangun Muka Raya, RT.11/RW.14, Rawamangun, Kec. Pulo Gadung, \\ Kota Jakarta Timur, Daerah Khusus Ibukota Jakarta 13220 \\ *Email: bagasdarmawan_1410619047@mhs.unj.ac.id
}

\begin{abstract}
Abstrak
Program Kreativitas Mahasiswa ini dilakukan untuk mengetahui dan mengedukasi masyarakat tentang transportasi umum di Jakarta. Metode yang kami lakukan adalah pembuatan Sosial dan menyebarkan form kepada masyarakat untuk mengetahui pendapat dan saran mereka terhadap transportasi umum khususnya pada masa pandemi ini serta mengajak masyarakat berdiskusi via Live Streaming youtube. Hasil dari program ini menjunjukan bahwa masyarakat sudah mengetahi dan paham tentang protokol-protokol yang harus dipatuhi untuk menggunakan. Dengan terlaksananya program ini kami dapat mengetahui bahwa sosial media sangat penting untuk mensosialisasikan aturan-aturan baru terhadap masyarakat khususnya pada masa genting ini.
\end{abstract}

Kata kunci: Masyarakat, Media, Transportasi

\section{PENDAHULUAN}

Transportasi merupakan suatu bidang kegiatan yang sangat penting dalam kehidupan masyarakat Indonesia. Fungsi transportasi adalah memindahkan orang dan/atau barang dari satu tempat ke tempat lain dengan menggunakan sistem tertentu untuk tujuan tertentu. Seiring meningkatnya perkembangan transportasi maka meningkat pula masalah. Kepemilikan kendaraan pribadi menyebabkan padatnya jalan raya karena telah melebihi kapasitas terutama di jam sibuk seperti jam pergi-pulang kantor. Solusinya adala penggunaan transportasi publik masal oleh masyarakat.

Menurut Nasution (2013 : 2-3), transportasi adalah pemindahan benda dan manusia dari tempat satu atau tempat asal ke tempat tujuan. Sedangkan transportasi publik atau transportasi umum adalah layanan angkutan pemindahan manusia oleh sistem perjalanan kelompok atau bersama yang digunakan oleh masyarakat umum dari satu tempat ke tempat lain yang biasanya dikelola oleh suatu badan usaha. DKI Jakarta sendiri, selama beberapa tahun kebelakang telah mengebangkan sistem transportasi publik yang terintegrasi satu sama lain. Tranportasi publik di Jakarta antara lain adalah angkutan kota (angkot) yang sekarang dimodernisasi menjadi Mikrotrans, Transjakarta, Kereta Rel Listrik (KRL) Commuterline, MRT Jakarta, dan LRT Jakarta.

Selama lima tahun terakhir, transportasi publik di Jakarta telah mengalami peningkatan pelanggan yang cukup signifikan. Dikutip dari website PT. Transjakarta (2020), perusahaan tersebut telah mencatat rekor 1 juta pelanggan pada bulan Februari lalu. Hal ini juga selaras dengan peningkatan pelanggan mada moda transportasi lain seperti MRT Jakarta, LRT Jakarta, dan Kereta Rel Listrik (KRL) Commuterline yang menghubungkan ibu kota Jakarta sebagai pusat perekonomian dengan kota satelit lainnya. Dengan peningkatan pelanggan tersebut, dibutuhkan informasi dan sosialisasi yang akurat, efektif, dan efisien untuk menginformasikan segala sesuatu mengenai transportasi publik tersebut. Oleh karena itu, kami melakukan program kreativitas 
mahasiswa berupa media informasi dan sosialisasi mengenai transportasi publik Jakarta, bernama Jakarta Transportation Info (Jaktransfo).

Menurut Gunardi (2018 : 6-7), Media informasi merupakan sistem untuk menyatukan dan menyusun kembali informasi-informasi yang diperoleh sehingga menjadi bahan yang berguna bagi orang lain. Media informasi ini dapat berupa; Twitter, Instagram, Facebook, website, aplikasi, dan lain lain. Dalam sistem transportasi publik di Jakarta, informasi disampaikan oleh pengelola kepada pelanggan transportasi publik mayoritas melalui media sosial resmi pada berbagai platform, ataupun melalui aplikasi seperti traffi, moveit, krl access, dan lain lain. Namun bagaimana jika pelanggan ingin menggunakan berbagai transportasi publik dalam sekali perjalanan? Maka mereka diharuskan mencari informasi melalui berbagai media yang berbeda. Tentunya hal tersebut tidaklah efisien.

Berdasarkan artikel yang ditulis oleh Bukit (2019 : 3-4), disebutkan pada zaman sekarang, telah dikenal era digital firm dimana sistem informasi secara masif banyak digunakan adalah internet. Dikutip dari Bariyyah and Permatasari (2017 : 2). Dengan memanfaatkan kecanggihan internet. Masyarakat dimungkinkan untuk memperoleh informasi dan edukasi sebanyak mungkin tanpa terhambat oleh ruang dan waktu. Dalam program kali ini, kami membuat sebuah akun media informasi bernama Jakarta Transportation Info (Jaktransfo). Jaktransfo adalah media informasi dan sosialisasi berbasis media sosial Instagram yang bertujuan untuk memberikan informasi serta mengedukasi masyarakat khususnya pelanggan transportasi publik. Sasaran utama dari Jaktransfo adalah pelanggan baru transportasi publik yang membutuhkan informasi satu pintu mengenai transportasi publik di Jakarta. Dengan Jaktransfo, mereka dapat mengetahui rute mana yang beroperasi, keadaan dalam halte ataupun stasiun besar, informasi terbaru dari jalur transportasi, hingga etika dalam menggunakan transportasi publik.

Jakarta Tranportation Info (Jaktransfo) juga mengedukasi masyarakat untuk beralih menggunakan transportasi publik. Hal ini dimaksudkan agar transportasi publik di Jakarta terus mengalami peningkatan pelanggan dan peningkatan kualitas, serta mengurangi kemacetan dan polusi di DKI Jakarta.

\section{METODE}

Berdasarkan uraian diatas, metode pelaksanaan Kegiatan Program Kreativitas Mahasiswa (PKM) Jakarta Transportation Info (Jaktransfo) dimulai dengan pembuatan akun media sosial Jaktransfo melalui Instagram. Hal tersebut bertujuan untuk menjadikan Instagram Jaktransfo sebagai media informasi satu pintu mengenai transportati publik di Jakarta. Dikarenakan adanya wabah COVID-19 yang bertepatan dengan pelaksanaan kegiatan tersebut, maka informasi yang diberikan oleh Jaktransfo berfokus pada permasalahan dan pencegahan penularan COVID-19 pada transportasi publik. Hal ini dilakukan agar para pelanggan transportasi publik yang masih harus menggunakan transportasi publik untuk berpergian, mengetahui protokol kesehatan yang harus dilakukan.

Untuk lebih meningkatkan pengetahuan masyarakat mengenai transportasi publik, Jaktransfo melakukan kegiatan lanjutan berupa diskusi live streaming yang diadakan di Youtube Jaktransfo pada Jumat, 1 Mei 2020, pukul 18.30 sampai selesai. Diskusi bertema "Transportasi Dikala Pandemi" ini bertujuan untuk memberikan informasi yang tidak dapat atau tidak sempat diberikan melalui media sosial Instagram dikarenakan berbagai faktor. Kegiatan kemudian dilanjutkan dengan penyebaran kuesioner dengan google form. Pada kuesioner ini, kami dari Jaktransfo fokus bertanya kepada responden mengenai pencegahan penularan COVID-19 pada transportasi publik khususnya pada tata hidup kenormalan baru dimulai.

\section{HASIL DAN PEMBAHASAN}

Hasil dari program yang kami laksanakan direspon dengan baik oleh masyarakat. Dimulai dari 22 Maret 2020 sampai dengan 01 Juni 2020 akun Instagram Jaktransfo telah mendapatkan 55 pengikut. Dari konten informatif dan edukasi yang diunggah, kami telah memposting 21 konten dan mendapatkan 1.021 likes. Konten informatif yang diposting merupakan kumpulan informasi yang kami dapatkan dari media resmi dan kredibel. Konten yang diposting juga didesain semenarik dan seinformatif mungkin agar masyarakat yang melihatnya tidak merasa bosan dan terlihat monoton. 
Kemudian, kegiatan selanjutnya yang dilakukan adalah diskusi live streaming yang diadakan pada akun Youtube resmi Jaktransfo. Diskusi bertema "Transportasi Dikala Pandemi" ini sebelumnya telah dipromosikan melalui sosial media resmi Jaktransfo dan juga media sosial para founder. Penyebaran poster acara dilakukan dengan berbagai media sosial lainnya, seperti Whatsapp, Line, dan sebagainya. Tujuan dilakukan acara pada live streaming ini diharapkan dapat menginformasikan berbagai hal mengenai apa yang harus dilakukan sebagai pengguna transportasi publik dikala pandemi. Namun disayangkan, ketika baru dimulainya live streaming, terdapat kesalahan teknis yang mengakibatkan dibatalkannya kegiatan tersebut.

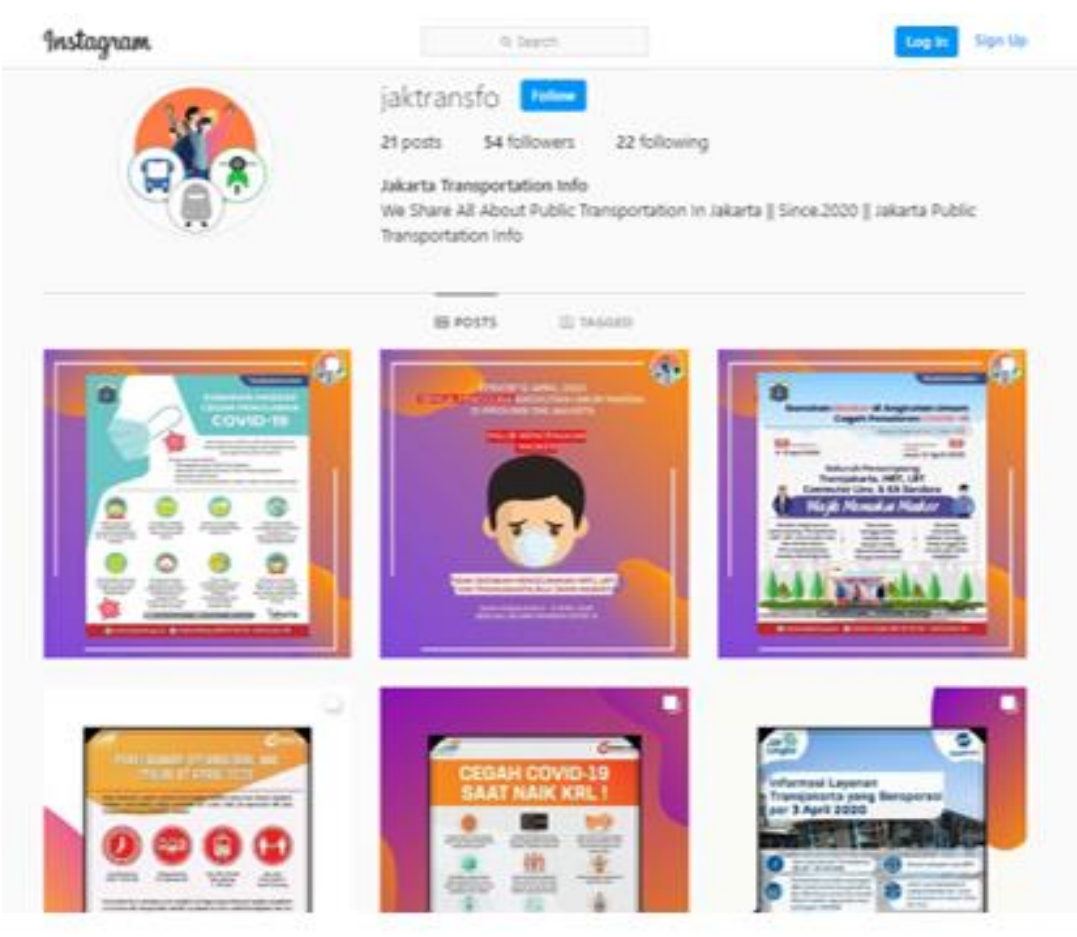

Gambar 1. Tampilan Akun Instagram Jaktransfo

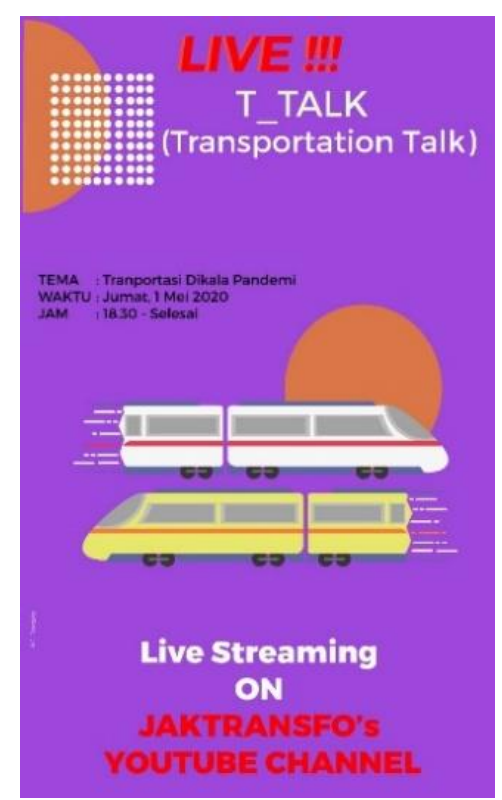

Gambar 2. Poster Webinar T_TALK (Transportation Talk) 
Tiga hari setelah dilaksanakannya live streaming, kami menyebarkan kuesioner yang bertujuan untuk mengetahui pendapat dan saran masyarakat mengenai pencegahan penularan COVID-19 pada transportasi publik, khususnya jika tata hidup kenormalan baru dimulai. Untuk menarik minat masyarakat mengisi kuesioner ini, selain kami menyebarkan kuesioner ke ruang obrolan dan media sosial, kami juga memberikan hadiah berupa saldo OVO / Gopay sebesar Rp. 100.000 kepada 5 orang (Rp. 20.000 / Orang) yang memiliki pendapat dan saran terbaik serta relevan untuk dilaksanakan.

Hasilnya, terdapat 14 orang yang telah mengisi kuesioner yang diberikan dengan presentase umur 18 tahun sebanyak 4 orang, 19 tahun sebanyak 9 orang, dan 25 tahun sebanyak 1 orang. Keseluruhan pendapat dan saran yang diberikan sangat relevan dengan apa yang terjadi di lapangan, mudah untuk di lakukan dan sesuai dengan harapan kami.

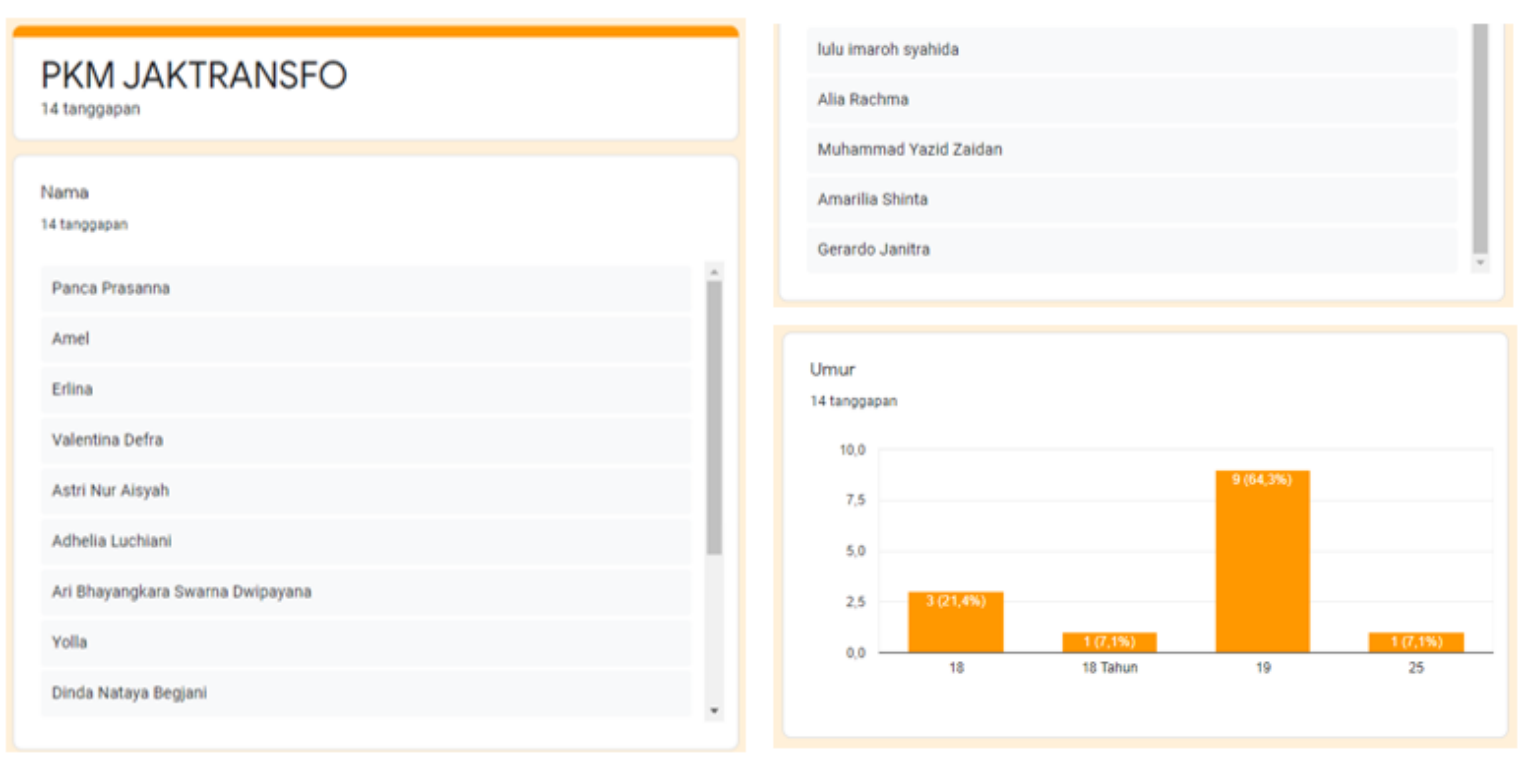

Gambar 3. Hasil dan Sebaran responden google form evaluasi webinar

Dari form kuesioner yang telah diisi, mayoritas responden telah mengetahui dan menyadari protokol protokol kesehatan yang diperlukan dalam transportasi publik. Protokol kesehatan tersebut meliputi selalu menggunakan masker, membawa hand sanitizer, mengurangi kontak terhadap benda benda di sekitar, serta mematuhi aturan jaga jarak fisik atau physical distancing yang telah ditetapkan sesuai standar badan kesehatan dunia. Responden juga memberikan beberapa saran mengenai solusi penurunan kepadatan pada transportasi publik agar physical distancing dapat efektif dilakukan. Cara yang paling efektif adalah penambahan armada dan mempersingkat headway atau jarak waktu antar satu armada dengan armada lain. Cara ini dinilai efektif karena penumpang dapat dibagi ke dalam beberapa armada sehingga tidak menumpuk pada satu armada saja.

Responden juga memberikan pendapat bahwa setelah selesainya pandemi dan masuk ke fase kenormalan baru, tetap diperlukan adanya protokol kesehatan tertentu agar transportasi publik tidak menjadi cluster baru penyebaran virus COVID-19 gelombang selanjutnya. Beberapa hal yang pertu diperhatikan sekaligus dibenahi adalah masalah kebersihan, layanan, dan sarana prasarana penunjang transportasi publik. Dengan pembenahan ini, diharapkan transportasi publik tetap menjadi andalan transportasi masyarakat ibu kota maupun kota satelit lainnya serta transportasi publik tetap menjadi tempat aman bagi para penggunanya.

\section{KESIMPULAN}

Berdasarkan penjelasan dan analisa yang telah kami berikan, maka dapat disimpulkan bahwa: Masyarakat pengguna fasilitas transportasi umum telah paham dan melakukan protokoprotokol yang diwajibkan pemerintah untuk menggunakan transportasi umum pada masa pandemi. Berdasarkan data yang kami terima, bahwa profil responden didominasi oleh remaja dengan usia 
18-25 tahun. Masa pandemi membuat kebanyakan orang untuk berdiam dirumah dan membuat terbatasnya informasi yang diterima. Hal ini menjadikan sosial media menjadi salah satu media pencari informasi yang dimanfaatkan oleh masyarakat. Dari hasil data yang kami dapatkan, responden mengalami kecemasan untuk tertular COVID-19. Walau sudah memenuhi protokolprotokol yang diberikan, ketakutan untuk tertular masih tinggi karena penuhnya antrean untuk menaiki transportasi umum yang disebabkan pengurangan armada.

\section{DAFTAR PUSTAKA}

Bariyyah, K., \& Permatasari, D. (2017). Pelatihan Pemanfaatan Media Online dalam Layanan Bimbingan Konseling Bagi Konselor Sekolah Menengah Pertama di Kabupaten Pamekasan Madura. Dedication: Jurnal Pengabdian Masyarakat, 1(1), 63-69.

Bukit, F. R. A., AS, G. G., Irvan, I., \& Fahmi, F. (2019). Pembuatan Website Katalog Produk UMKM Untuk Pengembangan Pemasaran dan Promosi Produk Kuliner. JPPM (Jurnal Pengabdian dan Pemberdayaan Masyarakat), 3(2), 229-236.

Gunardi, Harjanti. 2018. Media Informasi Di Taman Kanak Kanak Pembina. Thesis. UIN Sunan Kalijaga Yogyakarta

Nasution, M. Nur. 2013. Manajemen Transportasi. Bogor: Ghalia Indonesia

PT. Transjakarta. 2020. Capai Satu Juta Pelanggan Per Hari, Transjakarta Sampaikan Terima Kasih Kepada Pelanggan. Accessed May 30, 2020. Transjakarta.Co.Id. 